\title{
Anizotropia mikrostruktury płaszcza cementowego w aspekcie homogeniczności świeżego zaczynu cementowego
}

\begin{abstract}
Skuteczność izolowania stref przepuszczalnych w przestrzeni pozarurowej oraz międzyrurowej zależy w głównej mierze od rodzaju zastosowanego zaczynu uszczelniającego oraz jego właściwości reologicznych. W związku z tym niezbędne jest modyfikowanie oraz projektowanie innowacyjnych receptur zaczynów, które będą spełniały szereg wymagań. Ważnym czynnikiem po zatłoczeniu zaczynu cementowego jest uzyskanie jednorodnej struktury płaszcza cementowego, na której utworzenie znacznie wpływa homogeniczność świeżego (płynnego) zaczynu uszczelniającego. W publikacji omówiono wpływ jednorodności oraz związanej z nią stabilności sedymentacyjnej zaczynu na anizotropię mikrostruktury tworzącego się płaszcza cementowego. Zaprezentowano wyniki badań mikrostruktury płaszcza cementowego powstałego z zaczynu zmodyfikowanego w celu uzyskania homogenicznej struktury oraz porównano je z parametrami płaszcza cementowego, w którym widoczne są niejednorodności rozpatrywanego ośrodka.
\end{abstract}

Słowa kluczowe: anizotropia, ortotropia, sedymentacja, zaczyn cementowy, mikrostruktura porowa, porowatość, odstój wody.

\section{Anisotropy of the microstructure of the cement sheath in terms of the homogeneity of the fresh cement slurry}

The effectiveness of the isolation of permeable zones in annular space is largely dependent on the type of the applied cement slurry. Therefore, it is necessary to modify and design innovative slurries which will meet a series of requirements. An important factor is to obtain a homogeneous structure of the cement sheath after slurry displacement which significantly impacts the homogeneity of the fresh (liquid) slurry. The publication discusses the impact of homogeneity and related sedimentation stability of the slurry on the anisotropy of the cement sheath microstructure. Test results are presented, of the cement sheath microstructure based on slurry, modified to obtain a homogeneous structure and compared with the parameters of the cement sheath, wherein were the visible inhomogeneities in the considered medium.

Key words: anisotropy, orthotropic, sedimentation, cement slurry, porous microstructure, porosity, free water.

\section{Wprowadzenie}

Podczas projektowania receptury zaczynu cementowego przeznaczonego do uszczelniania, w szczególności otworów gazowych, jednym z najważniejszych czynników jest uzyskanie nieprzepuszczalnej dla gazu oraz mocno skompaktowanej matrycy płaszcza cementowego (rysunek 1). Wystąpienie po związaniu zaczynu tzw. niejednorodności bądź wolnych przestrzeni (rysunek 2) w formie tzw. porów komuni- katywnych prowadzi do powstawania przepływu płynu (cieczy bądź gazu) przez mikrostrukturę stwardniałego zaczynu cementowego [2, 6, 14, 15]. Zjawisko takie najczęściej może być obserwowane podczas nieodpowiedniego doboru parametrów reologicznych zaczynu, czego efektem może być rozwarstwienie frakcji zaczynu o różnych gęstościach w funkcji głębokości wypełnianej przestrzeni pierścieniowej bądź po- 
zarurowej. W celu wyeliminowania frakcjonowania zaczynu o różnych gęstościach podczas projektowania receptury należy odpowiednio dobierać parametry zaczynu, który po związaniu będzie się charakteryzował jednorodną i skompaktowaną strukturą, niską przepuszczalnością i porowatością, a wytrzymałość mechaniczna będzie porównywalna w poszczególnych punktach pomiaru $[5,7,11,13]$.

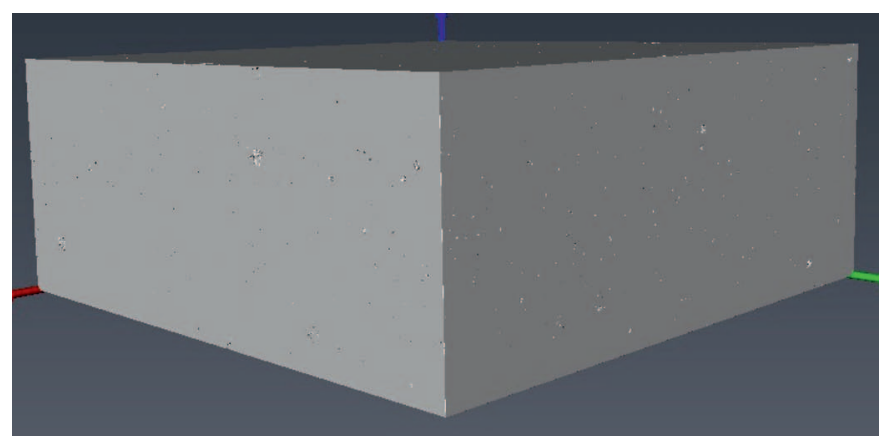

Rys. 1. Obraz rentgenowski skompaktowanej matrycy płaszcza cementowego (niska porowatość próbki)

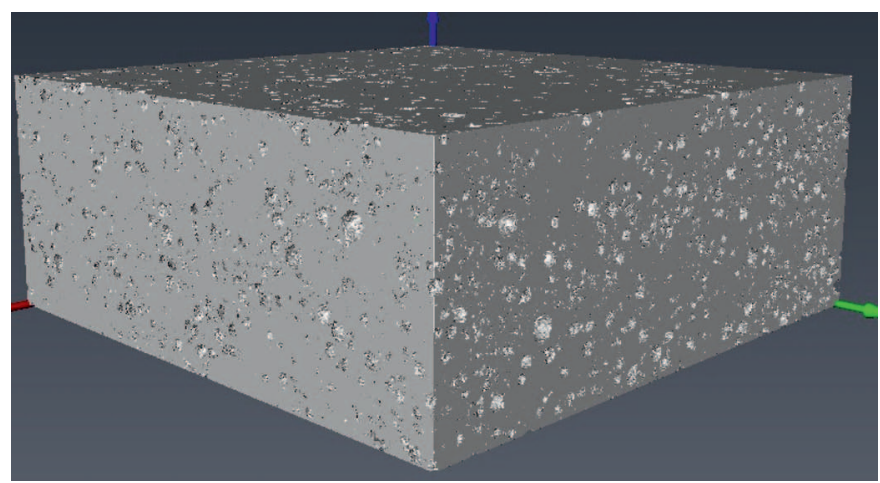

Rys. 2. Obraz rentgenowski matrycy płaszcza cementowego o wysokiej porowatości

Dodatkowo oprócz podstawowych parametrów decydujących o efektywności uszczelnienia kolumn rur okładzinowych, takich jak gęstość zaczynu, filtracja, optymalne parametry reologiczne oraz czas gęstnienia, szczególną uwagę należy zwrócić na stabilność sedymentacyjną zaczynu cementowego. Efekt sedymentacji obserwowany jest podczas rozdzielania się poszczególnych frakcji zaczynu w zależności od ich gęstości. Najczęściej zjawisko to jest obserwowane w otworach odchylonych od pionu, zachodzi jednak również w otworach pionowych, ale jest trudniejsze do wychwycenia $[4,8]$.

Ważny aspekt stanowi zachowanie jednorodności struktury płaszcza cementowego na całej długości rozpatrywanego interwału. Wpływa to na długoletnią trwałość i szczelność płaszcza w trakcie późniejszej eksploatacji odwiertu. Zaczyn cementowy o niskiej stabilności sedymentacyjnej, na skutek osadzania się frakcji o większej gęstości w dolnej części przestrzeni pierścieniowej, powoduje powstawa- nie anizotropowej mikrostruktury ośrodka w funkcji głębokości. Zjawisko takie jest niepożądane ze względu na możliwość miejscowego osłabienia struktury stwardniałego zaczynu poprzez wzrost porowatości oraz obniżenie parametrów mechanicznych (wytrzymałość na ściskanie, wytrzymałość na zginanie, przyczepność do rur stalowych i do formacji skalnej) w górnych partiach płaszcza cementowego. Nadmienić należy, że destabilizacja parametrów mechanicznych stwardniałego zaczynu może się również przyczynić do wzrostu przepuszczalności płaszcza cementowego w jego górnych partiach $[1,3,9]$.

Dodatkowym czynnikiem wpływającym na konieczność modyfikowania zaczynów cementowych w celu wyeliminowania sedymentacji zaczynu jest fakt, że w niejednorodnym zaczynie cementowym w górnych partiach uszczelnianej przestrzeni pierścieniowej następuje zmniejszenie gęstości zaczynu oraz wzrost wydzielającej się z niego wody wolnej (rysunek 3). Gromadzi się ona wówczas w górnej części ściany otworu, a w przypadku otworu poziomego lub silnie odchylonego od pionu po związaniu zaczynu może powodować powstawanie dróg migracji gazu wzdłuż kolumny rur. Powstałe na skutek dużej sedymentacji i wody wolnej osłabienie stwardniałego zaczynu, obniżenie parametrów mechanicznych oraz wzrost porowatości mogą skutkować pojawianiem się nieszczelności w otworze, czego następstwem może być wystąpienie przepływu mediów złożowych [4].

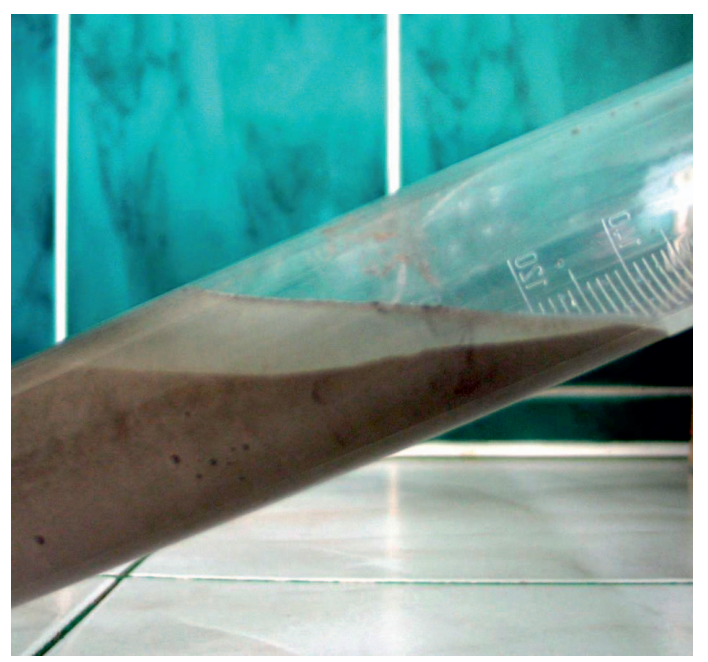

Rys. 3. Efekt zwiększonego odstoju wody w zaczynie cementowym

Nawiązując do parametru opisywanego mianem wody wolnej (odstoju wody), nadmienić należy, że wymagania dotyczące zaczynów cementowych przeznaczonych do uszczelniania kolumn rur w otworach odchylonych od pionu czy horyzontalnych są bardziej restrykcyjne niż w otworach pionowych. Wolna woda w zaczynie przeznaczonym do cementowania otworów pionowych nie powinna przekraczać warto- 
ści normowej równej 1,4\% (według API Spec 10), natomiast w przypadku cementowania otworów odchylonych od pionu powyżej $60^{\circ}$ woda wolna musi być całkowicie wyeliminowana. Parametr ten jest niejako powiązany ze stabilnością sedymentacyjną i homogenicznością zaczynu cementowego. Wynika to z faktu, że zaczyn ulegający destabilizacji podczas osiadania fazy cięższej wydziela część wody w górnej części słupa zaczynu cementowego [10, 12].

\section{Działanie zapobiegające destabilizacji zaczynu cementowego}

Niehomogeniczne zaczyny cementowe skutkujące powstawaniem anizotropowej struktury płaszcza cementowego nie są akceptowane zarówno w przypadku otworów pionowych, jak również wtedy, gdy mamy do czynienia z otworem mocno odchylonym lub horyzontalnym. Wynika to $\mathrm{z}$ faktu, że zagrożone są parametry mechaniczne i strukturalne tworzącego się stwardniałego zaczynu, mające wpływ na prawidłowość izolacji międzystrefowej. Analizując zależności takich parametrów jak woda wolna i granica płynięcia od koncentracji środków dyspergujących, widoczny jest niewielki przedział, wewnątrz którego zaczyn cementowy wykazuje cechy zarówno cieczy, jak i substancji stabilnej sedymentacyjnie. W warunkach podwyższonej temperatury kontrola koncentracji dyspergatorów jest bardzo trudna w tak małym zakresie. W związku z tym niezbędne staje się zastosowanie środków opóźniających wiązanie i gęstnienie zaczynu w celu zwiększenia zakresu, w obrębie którego można utrzymać niską wartość lepkości plastycznej oraz wolnej wody. Sedymentacja fazy stałej oraz współtowarzyszący odstój wody w zaczynie cementowym to problemy prowadzące do powstawania anizotropowej mikrostruktury stwardniałego zaczynu na skutek zmian w gę- stości wiążącego zaczynu, a następnie do powstawania dróg migracji gazu w płaszczu cementowym $[3,4]$.

Działania zapobiegające powstawaniu temu zjawisku polegają głównie na stosowaniu dodatków zapobiegających tworzeniu się wody wolnej i sedymentacji fazy stałej w zaczynie. Dodatki i domieszki przeciwdziałające wytrącaniu ciężkich frakcji powodują utrzymanie stabilnej wartości granicy płynięcia na poziomie możliwości utrzymania cyrkulacji oraz pokonywania oporów hydraulicznych tłoczenia, które nie doprowadzą do szczelinowania lub innych komplikacji.

W tym celu stosuje się środki mające właściwości absorpcyjne dużych ilości wody, co powoduje homogenizację zaczynu cementowego. Ponadto innowacyjne dodatki i domieszki do zaczynów cementowych poprawiają stabilność sedymentacyjną poprzez zwiększenie lepkości wody międzykrystalicznej [9].

W dalszej części publikacji przedstawiono wyniki badań zaczynów z dodatkami, które w znacznym stopniu zredukowały ilość wody wolnej oraz przyczyniły się do wyeliminowania destabilizacji zaczynu cementowego na skutek powstawania sedymentacji fazy stałej w zaczynie.

\section{Przebieg prac badawczych}

Badania mające na celu określenie homogeniczności zaczynu oraz wpływu tego parametru na anizotropię płaszcza cementowego wykonywano na podstawie norm: PN-85/G-02320 Cementy $i$ zaczyny cementowe do cementowania $w$ otworach wiertniczych; PN-EN 10426-2 Przemyst naftowy i gazowniczy. Cementy i materialy do cementowania otworów. Część 2: Badania cementów wiertniczych oraz API Spec 10 Specification for materials and testing for well cements.

Zaprezentowany w niniejszej publikacji cykl badawczy polegał na pokazaniu wpływu niejednorodności zaczynu cementowego na anizotropię tworzącej się mikrostruktury płaszcza cementowego. Porównane zostały dwie receptury dla warunków otworowych o temperaturze $30^{\circ} \mathrm{C}$ i ciśnieniu $5 \mathrm{MPa}$ (sporządzone przy użyciu cementu wiertniczego klasy G HSR. Pierwsza receptura (bazowa) to zaczyn porównawczy, w którym obserwowano znaczną sedymentację zaczynu, natomiast druga receptura to zaczyn zmodyfikowany w celu wyeliminowania niepożądanego zjawiska sedymentacji. Receptury zaczynów zamieszczono w tablicy 1. Mo- dyfikacja składu zaczynu polegała na zastosowaniu dodatku polimeru wielkocząsteczkowego w ilości 4\%, dodatku lateksu w ilości 10\% oraz 2-procentowej ilości stabilizatora lateksu. Takie działanie (głównie dodatku polimeru wielkocząsteczkowego) miało na celu zwiększenie lepkości zaczynu i tym samym utrzymanie fazy stałej w całej objętości słupa zaczynu, nie powodując jego rozwarstwiania. Dodatkowo obniżono współczynnik wodno-cementowy. Skład ilościowy i jakościowy pozostałych dodatków i domieszek nie uległ zmianie w stosunku do zaczynu bazowego.

Zaczyn po wprowadzeniu modyfikacji posiadał gęstość $1,88 \mathrm{~kg} / \mathrm{dm}^{3}$, nie wykazywał odstoju wody oraz uzyskano znacznie niższą $\left(28 \mathrm{~cm}^{3} / 30 \mathrm{~min}\right)$ niż w przypadku zaczynu bazowego $\left(84 \mathrm{~cm}^{3} / 30 \mathrm{~min}\right)$ wartość filtracji. Zarówno lepkość plastyczna, jak i granica płynięcia nieznacznie wzrosły w porównaniu z zaczynem bazowym, natomiast czas gęstnienia uległ niewielkiemu (około 20-minutowemu) skróceniu, co może być thumaczone wzrostem lepkości zaczynu. Parametry zaczynu bazowego i poddanego modyfikacji zestawiono w tablicy 1. 
Tablica 1. Składy i parametry zaczynów cementowych

\begin{tabular}{|c|c|c|c|}
\hline \multirow{2}{*}{\multicolumn{2}{|c|}{$\frac{\text { Dla warunków (temp./ciśn.) }}{\text { SKŁAD }}$}} & \multicolumn{2}{|c|}{$30^{\circ} \mathrm{C} / 5 \mathrm{MPa}$} \\
\hline & & Bazowy & Modyfikacja \\
\hline \multicolumn{2}{|c|}{ Woda wodociągowa } & $\mathrm{w} / \mathrm{c}=0,48$ & $\mathrm{w} / \mathrm{c}=0,45$ \\
\hline \multicolumn{2}{|c|}{ Dodatek odpieniający } & $0,3 \%$ & $0,3 \%$ \\
\hline \multicolumn{2}{|l|}{$\mathrm{KCl}$} & $3,0 \%$ & $3,0 \%$ \\
\hline \multicolumn{2}{|c|}{ Dodatek upłynniający } & $0,3 \%$ & $0,3 \%$ \\
\hline \multicolumn{2}{|c|}{ Dodatek antyfiltracyjny } & $0,2 \%$ & $0,2 \%$ \\
\hline \multicolumn{2}{|c|}{ Polimer wielkocząsteczkowy } & - & $4,0 \%$ \\
\hline \multicolumn{2}{|l|}{ Lateks } & - & $10,0 \%$ \\
\hline \multicolumn{2}{|l|}{ Stabilizator lateksu } & - & $1,0 \%$ \\
\hline \multicolumn{2}{|l|}{$\mathrm{CaCl}_{2}$} & $4,0 \%$ & $4,0 \%$ \\
\hline \multicolumn{2}{|l|}{ Mikrocement } & $20,0 \%$ & $20,0 \%$ \\
\hline \multicolumn{2}{|c|}{ Cement CEM G HSR } & $100,0 \%$ & $100,0 \%$ \\
\hline \multicolumn{2}{|c|}{ Dodatek spęczniający } & $0,3 \%$ & $0,1 \%$ \\
\hline \multicolumn{4}{|c|}{ PARAMETRY ZACZYNÓW } \\
\hline \multicolumn{2}{|l|}{ Gęstość $\left[\mathrm{kg} / \mathrm{dm}^{3}\right]$} & 1,86 & 1,88 \\
\hline \multicolumn{2}{|l|}{ Rozlewność [mm] } & 180 & 230 \\
\hline \multicolumn{2}{|c|}{ Filtracja $\left[\mathrm{cm}^{3} / 30 \mathrm{~min}\right]^{*}$} & 84,0 & 28,0 \\
\hline \multicolumn{2}{|c|}{ Lepkość plastyczna $[\mathrm{mPa} \cdot \mathrm{s}]$} & 141,0 & 153,0 \\
\hline \multicolumn{2}{|c|}{ Granica płynięcia [Pa] } & 9,1 & 12,9 \\
\hline \multicolumn{2}{|c|}{ Wytrzymałość strukturalna [Pa] } & 4,3 & 7,2 \\
\hline Odstój wody [\%] & & 0,8 & 0,0 \\
\hline \multirow{2}{*}{$\begin{array}{l}\text { Czas gęstnienia } \\
\text { [godz.:min] }^{*}\end{array}$} & $30 \mathrm{Bc}$ & $2: 48$ & $2: 25$ \\
\hline & $100 \mathrm{Bc}$ & $3: 34$ & $3: 15$ \\
\hline
\end{tabular}

${ }^{*}$ Temperatura badania: $30^{\circ} \mathrm{C}$.

Czas osiągnięcia temperatury $=10$ minut.

Kluczowe badanie decydujące o homogeniczności świeżego zaczynu, czyli badanie stabilności sedymentacyjnej, wykonano przy użyciu kolumny do badania sedymentacji (rysunek 4) zgodnie z punktem 15.6 normy PN-EN 10426-2. W celu przeprowadzenia pomiaru zaczyn cementowy umieszczono w kolumnie sedymentacyjnej, następnie po 2 godzinach zmierzono gęstość w poszczególnych punktach pomiarowych (górna część kolumny pomiarowej, środkowa oraz dolna jej część kolumny pomiarowej). Zgodnie z normą, gdy zaczyn cementowy wykazuje stabilność sedymentacyjną, gęstości poszczególnych próbek zaczynu posiadają jednakową wartość. Natomiast jeżeli różnica wartości w poszczególnych punktach pomiarowych jest większa od $0,06 \mathrm{~kg} / \mathrm{dm}^{3}$, świadczy to o braku jednorodności zaczynu. Zgodnie z powyższym na podstawie pomiaru gęstości zaczynu w poszczególnych punktach określona została jego stabilność.

W celu ukazania zależności pomiędzy homogenicznością zaczynu cementowego i anizotropią powstałego stwardniałego zaczynu próbki z poszczególnych części kolumny po 14 dniach hydratacji poddano badaniom porowatości przy uży-

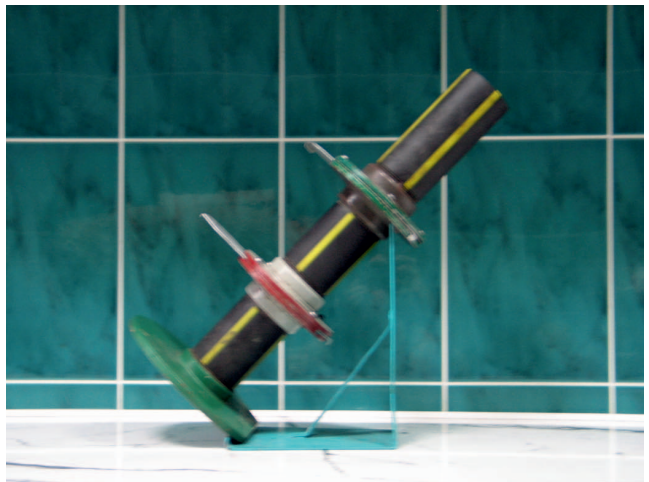

Rys. 4. Kolumna do pomiaru stabilności sedymentacyjnej zaczynu cementowego

ciu porozymetru rtęciowego AutoPore (rysunek 5). Badanie to umożliwiło przeprowadzenie analizy jakościowej stanu płaszcza cementowego w poszczególnych punktach. Określono najważniejsze parametry mikrostruktury, czyli: porowatość, średnicę progową porów, procentowy udział przestrzeni porowych o określonej średnicy oraz udział porów większych i mniejszych od średnicy progowej. Dodatkowo dla próbek stwardniałych zaczynów wykonane zostały badania wytrzymałości na ściskanie.

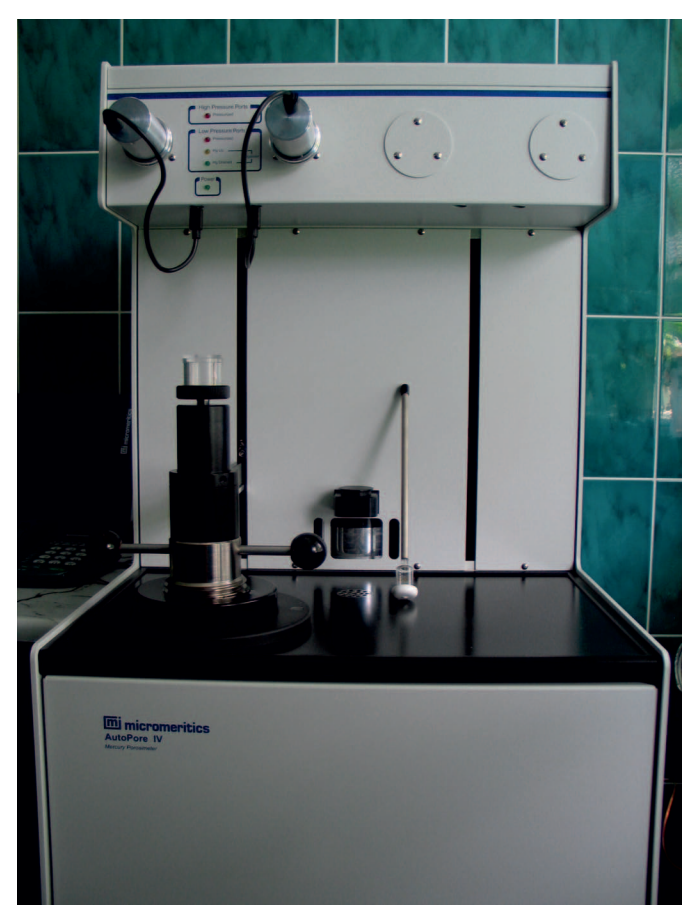

Rys. 5. Porozymetr rtęciowy AutoPore

Na podstawie wyników badań stabilności sedymentacyjnej stwierdzono, że zaczyn bazowy ulegał sedymentacji, jego gęstość wynosiła od $1,78 \mathrm{~kg} / \mathrm{dm}^{3}$ (górna część kolumny pomiarowej) do $1,96 \mathrm{~kg} / \mathrm{dm}^{3}$ w dolnej części kolumny. Wyniki zestawiono na rysunku 6. Taki brak homogeniczności znalazł przełożenie podczas badania powstałych z zaczynu próbek stwardniałego zaczynu. Zaobserwowano znaczne różni- 
ce w parametrach mechanicznych. Wytrzymałość na ściskanie po 14 dniach hydratacji stwardniałego zaczynu z górnej części kolumny wynosiła 11,2 MPa, natomiast próbka z dolnej części była niemal dwukrotnie mocniejsza (wytrzymałość na ściskanie 22,2 MPa). Również w przypadku porowatości zaobserwowano znaczne rozbieżności. Górna część stwardniałego zaczynu posiadała porowatość równą 44\% po 28 dniach hydratacji, zaś porowatość stwardniałego zaczynu z dolnej części kolumny po tym samym czasie hydratacji wynosiła $30,8 \%$. Średnica progowa próbki zawierała się w przedziale od 30,2 mikrometra w próbce z górnej części kolumny pomiarowej do 11,3 mikrometra $\mathrm{w}$ próbce $\mathrm{z}$ dolnej części. Uzyskane znaczne wartości tego parametru informują o możliwości wystąpienia mikroprzepływów. Powyższe wyniki badań zestawiono na rysunku 6 , gdzie wartości zobrazowane zostały zgodnie z punktem pomiaru kolumny sedymentacyjnej.
Analizując wyniki badań stabilności sedymentacyjnej zaczynu poddanego modyfikacjom stwierdzono, że zaczyn po dwóch godzinach kondycjonowania charakteryzował się stałą wartością gęstości, która wynosiła $1,88 \mathrm{~kg} / \mathrm{dm}^{3}$ we wszystkich punktach pomiarowych (górna, środkowa oraz dolna część kolumny pomiarowej). Rozbieżności w wartościach parametrów mechanicznych były niewielkie. Próbka stwardniałego zaczynu powstałego z górnej części kolumny posiadała wytrzymałość na ściskanie 22,2 MPa po 14 dniach hydratacji, natomiast próbka z dolnej części kolumny miała wytrzymałość równą $24 \mathrm{MPa}$. Również różnica w porowatości była niewielka (36,2\% - próbka z górnej części kolumny; 34,1\% - próbka z dolnej części kolumny). Zaobserwowano też znacznie niższe wartości średnicy progowej w przypadku próbek z zaczynu zmodyfikowanego w porównaniu z zaczynem bazowym. Parametr ten zawierał się w zakresie od 0,077 mikrometra $\mathrm{w}$ próbce $\mathrm{z}$ górnej części do 0,040 mikrometra w próbce

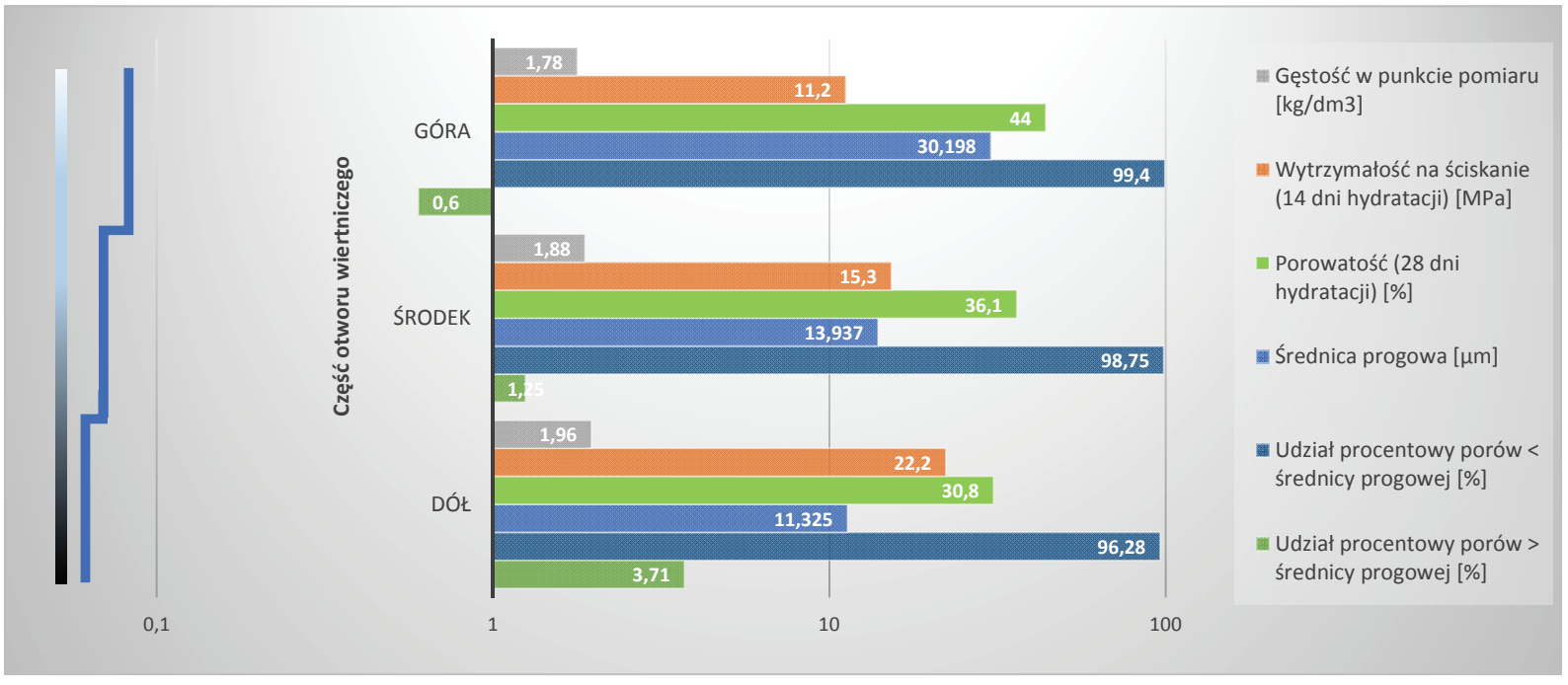

Rys. 6. Wykres zmian parametrów strukturalnych płaszcza cementowego w funkcji głębokości otworu wiertniczego (zaczyn bazowy)

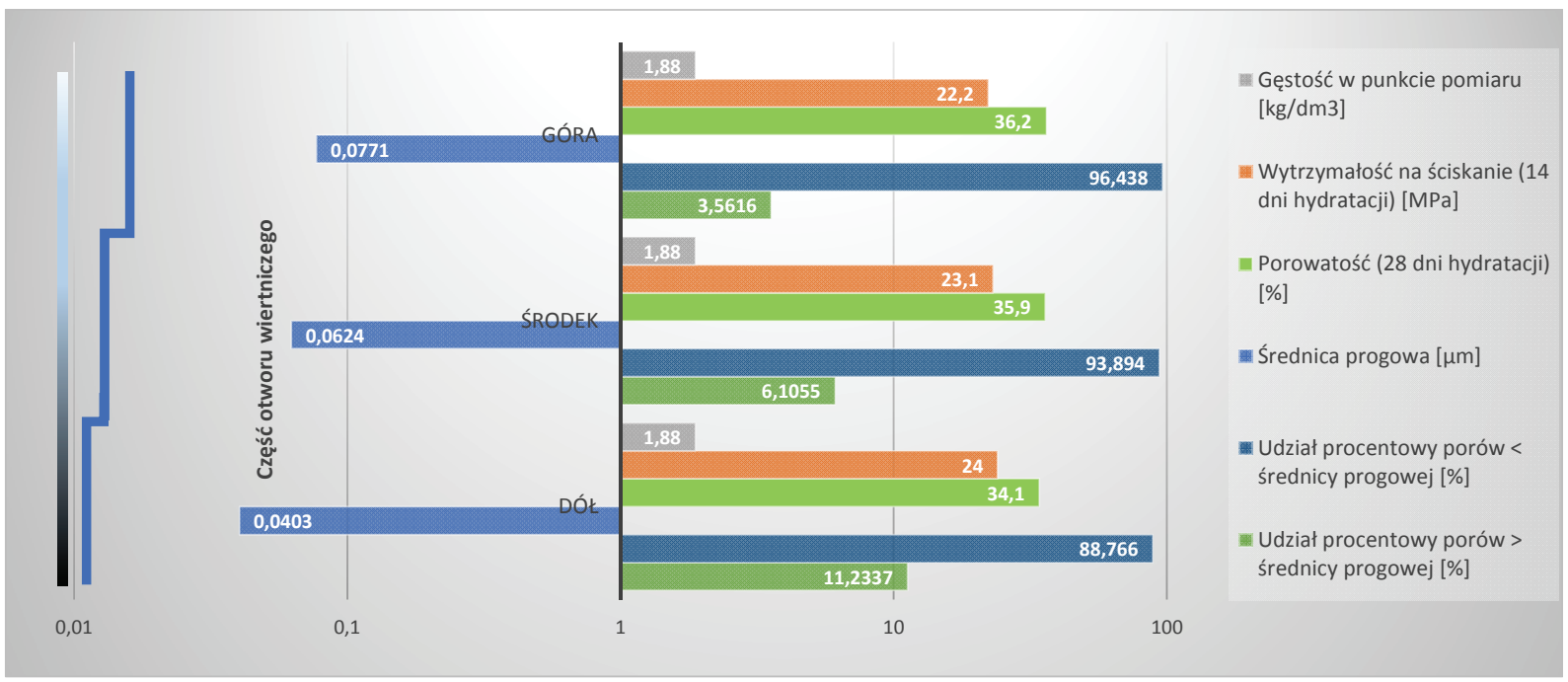

Rys. 7. Wykres zmian parametrów strukturalnych płaszcza cementowego w funkcji głębokości otworu wiertniczego (zaczyn zmodyfikowany) 
w dolnej części. Wartości te potwierdzają otrzymanie szczelnej i nieprzepuszczalnej matrycy płaszcza cementowego. Uzyskane wyniki badań przedstawiono na rysunku 7.

Brak homogeniczności zaczynu cementowego, skutkujący powstawaniem anizotropowej mikrostruktury płaszcza cementowego, w odniesieniu do jednostki głębokości widoczny jest również podczas interpretacji udziału przestrzeni porowych o określonych średnicach. W przypadku zaczynu ulegającego rozwarstwieniu podczas wiązania widoczne jest znaczne zróżnicowanie przebiegu krzywych procentowego udziału przestrzeni porowych o określonych średnicach (rysunek 8). Natomiast mikrostruktura płaszcza cementowego powstałego z zaczynu homogenicznego posiada porównywalny (niemal jednakowy) przebieg krzywych udziału przestrzeni porowych niezależnie od punktu pomiaru, co obrazuje rysunek 9.

Na podstawie uzyskanych wyników badań można wnioskować, że niejednorodna mikrostruktura płaszcza cementowego w funkcji głębokości otworu wiertniczego wynika

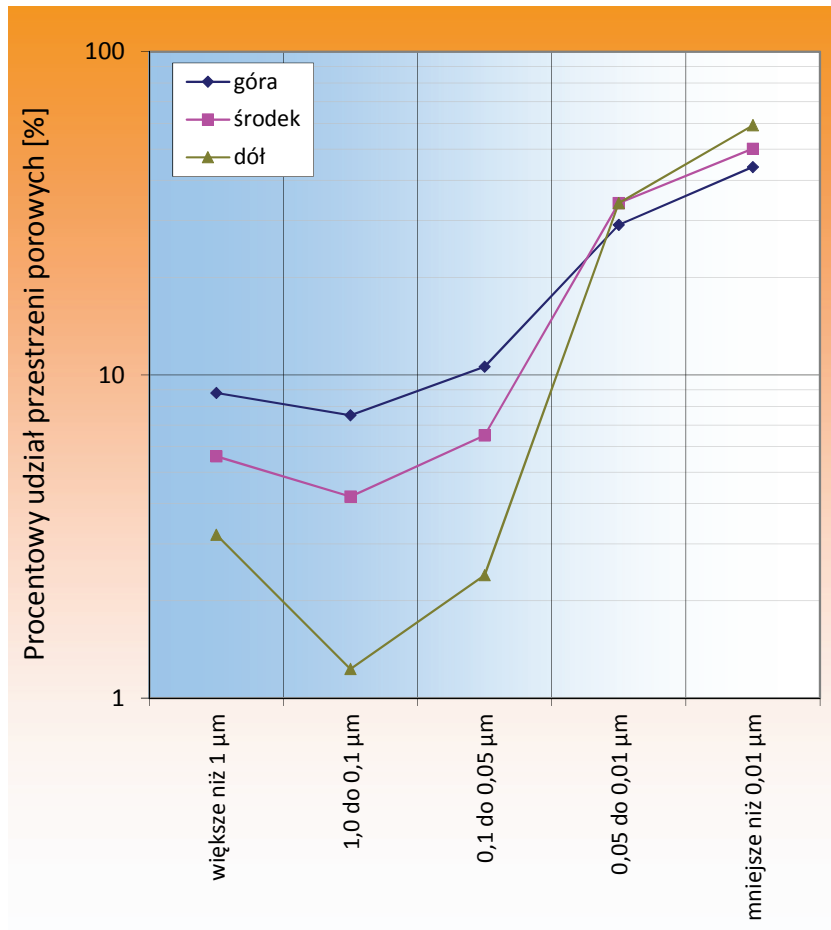

Przestrzenie porowe o średnicy

Rys. 8. Wykres procentowego udziału przestrzeni porowych o określonej średnicy (próbka bazowa) z braku homogeniczności świeżego zaczynu uszczelniającego. Powyższe znajduje potwierdzenie w wynikach badań stabilności sedymentacyjnej zaczynu, niejako skorelowanych z wynikami opisującymi zarówno parametry mechaniczne, jak i mikrostrukturalne stwardniałego zaczynu cementowego. Obserwowane znaczne różnice w parametrach opisujących mikrostrukturę płaszcza cementowego powstałego z zaczynu niezmodyfikowanego powstają na skutek osiadania ciężkich frakcji w świeżym zaczynie. Efektem tego jest proporcjonalny do głębokości wzrost takich parametrów jak: gęstość, wytrzymałość oraz udział porów większych od średnicy progowej. Powyższe wymusza projektowanie homogenicznych zaczynów, wykazujących jednorodność i stabilność sedymentacyjną. Przekłada się to na uzyskanie jednolitej konsystencji zaczynu w całej objętości wypełnianej przestrzeni pierścieniowej, a tym samym na trwałość i szczelność płaszcza cementowego na całej długości rozpatrywanego interwału.

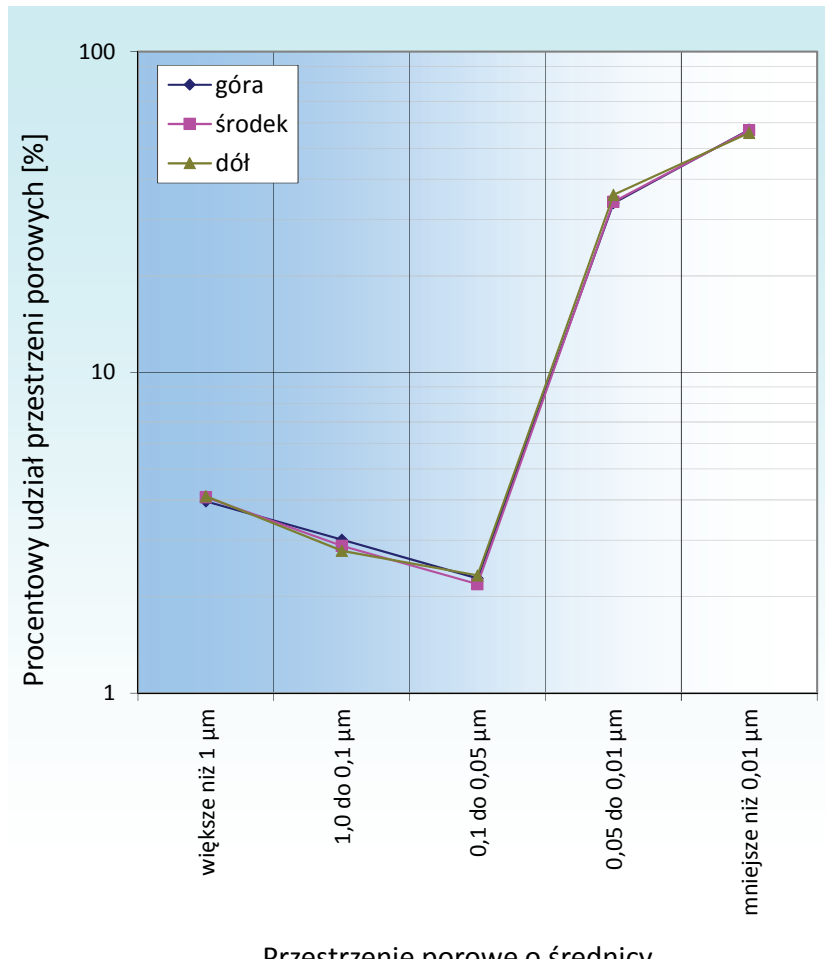

Przestrzenie porowe o średnicy

Rys. 9. Wykres procentowego udziału przestrzeni porowych o określonej średnicy (próbka po modyfikacji)

\section{Podsumowanie}

Zagadnienie anizotropii płaszcza cementowego nie jest poruszane zbyt często. Przyjmuje się, że stwardniały zaczyn cementowy jest (powinien być) jednorodny, jednak zrealizowane prace badawcze i uzyskane wyniki badań potwierdzają, iż zjawisko anizotropii płaszcza cementowego może być obserwowane w funkcji głębokości otworu wiertniczego przy nieodpowiednim doborze składu zaczynu cementowego. Ma to związek ze znacznymi głębokościami (długość danego interwału) cementowanej przestrzeni pierścieniowej i możliwością rozdzielenia się frakcji zaczynu. 
Należy zauważyć, że znacznie rzadziej można obserwować zjawisko ortotropii zaczynu, czyli różnic występujących prostopadle do osi otworu. Wiąże się to z niewielką szerokością rozpatrywanego odcinka płaszcza cementowego, który w tym właśnie wymiarze nie zmienia swoich parametrów.

$\mathrm{Na}$ podstawie zrealizowanych prac badawczych wysunięte zostały następujące wnioski:

- Mikrostruktura stwardniałego zaczynu cementowego może wykazywać anizotropowość ze względu na rozdzielanie się poszczególnych frakcji zaczynu wraz ze wzrostem głębokości otworu wiertniczego.

- Nieodpowiedni dobór dodatków, domieszek lub proporcji poszczególnych środków w recepturze zaczynu cementowego może prowadzić do braku jego stabilności sedymentacyjnej i utraty homogeniczności, czego efektem będzie anizotropia mikrostruktury płaszcza cementowego w funkcji głębokości.

- Wprowadzone modyfikacje receptury zaczynu miały na celu uzyskanie stabilnego pod względem sedymentacyjnym zaczynu cementowego, który po związaniu charak- teryzował się porównywalnymi wartościami parametrów opisujących mikrostrukturę badanej próbki.

- Przeprowadzone prace badawcze potwierdziły wpływ homogeniczności i stabilności sedymentacyjnej świeżego zaczynu na anizotropię mikrostruktury tworzącego się płaszcza cementowego.

- Poprzez wprowadzenie odpowiednich modyfikacji w recepturze możliwe było zaprojektowanie takiego zaczynu, który wykazywał jednorodną konsystencję oraz posiadał stałe (niezależnie od punktu pomiaru/głębokości) wartości parametrów opisujących mikrostrukturę płaszcza cementowego.

- Dzięki wprowadzonym modyfikacjom otrzymano stwardniały zaczyn cementowy o znacznie niższej niż w zaczynie bazowym wartości średnicy progowej (wartości poniżej $0,1 \mu \mathrm{m}$ ). Uzyskano porównywalny udział porów o określonych średnicach niezależnie od punktu pomiaru oraz parametry technologiczne na prawie niezmiennym poziomie, przez co płaszcz cementowy wykazał bardziej szczelną i skompaktowaną strukturę.

Prosimy cytować jako: Nafta-Gaz 2016, nr 11, s. 919-925, DOI: 10.18668/NG.2016.11.04

Artykuł nadesłano do Redakcji 14.07.2016 r. Zatwierdzono do druku 6.10.2016 r.

Artykuł powstał na podstawie pracy badawczej pt. Analiza możliwości poprawy stabilności sedymentacyjnej zaczynów cementowych - praca INiG - PIB na zlecenie MNiSW, nr zlecenia: 0036/KW/16/01, nr archiwalny: DK-4100/36/16.

\section{Literatura}

[1] Dębińska E.: Ocena działania dodatków opóźniajacych czas wiazania zaczynów cementowych na podstawie badań laboratoryjnych. Nafta-Gaz 2012, nr 4, s. 225-232.

[2] Dohnalik M., Zalewska J.: Korelacja wyników badań laboratoryjnych uzyskanych metoda rentgenowskiej mikrotomografii, jadrowego rezonansu magnetycznego i porozymetrii rtęciowej. Nafta-Gaz 2013, nr 10, s. 735-743.

[3] Kątna Z. i inni: Badania modelowe wpływu odstoju wody, sedymentacji i poczatkowego skurczu zaczynu cementowego na jakość uszczelniania rur $w$ otworach odchylonych od pionu i poziomych $w$ temperaturach do $85^{\circ} \mathrm{C}$. Praca naukowo-badawcza INiG, Kraków 1997.

[4] Kremieniewski M.: Modyfikacja przestrzeni porowej kamieni cementowych. Nafta-Gaz 2012, nr 3, s. 165-170.

[5] Kremieniewski M.: Wplyw warunków hydratacji na strukturę przestrzenna kamieni cementowych. Nafta-Gaz 2013, nr 1, s. $51-56$.

[6] Kremieniewski M., Rzepka M., Stryczek S., Wiśniowski R., Kotwica Ł., Złotkowski A.: Korelacja przepuszczalności i parametrów opisujacych strukturę stwardniałych zaczynów cementowych stosowanych do uszczelniania otworów $w$ rejonie Basenu Pomorskiego. Nafta-Gaz 2015, nr 10, s. 737-746.

[7] Kremieniewski M., Stryczek S., Kotwica Ł.: Zmiany w mikrostrukturze płaszcza cementowego w zależności od warunków hydratacji zaczynu. Nafta-Gaz 2014, nr 12, s. 918-926.

[8] Nelson B. i in.: Cementowanie otworów wiertniczych. Schlumberger Educational Service, Houston, Texas 1990.

[9] Rzepka M.: Zaczyny cementowe o wysokiej elastyczności kamienia cementowego. Nafta-Gaz 2011, nr 2, s. 113-119.
[10] Rzepka M., Stryczek S.: Laboratoryjne metody określania parametrów technologicznych świeżych zaczynów uszczelniajacych przed zabiegiem zwiazanym z procesem uszczelniania kolumn rur okładzinowych w otworach wiertniczych. Wiertnictwo, Nafta, Gaz 2008, t. 25, z. 2, s. 625-636.

[11] Stryczek S., Gonet A., Wiśniowski R., Złotkowski A.: Zaczyny uszczelniajace do wypetniania pustek $w$ górotworze solnym. Wiertnictwo, Nafta, Gaz 2011, t. 28, z. 1-2, s. 391-400.

[12] Stryczek S., Wiśniowski R., Gonet A., Ferens W.: Parametry reologiczne świeżych zaczynów uszczelniajacych $w$ zależności od czasu ich sporzadzania. Wiertnictwo, Nafta, Gaz 2009, t. 26, z. 1-2, s. 369-382.

[13] Stryczek S., Wiśniowski R., Gonet A., Złotkowski A.: The influence of time of rheological parameters of fresh cement slurries. AGH Drilling, Oil, Gas 2014, vol. 31, s. 123-133.

[14] Such P.: Przestrzeń porowa skat tupkowych. Nafta-Gaz 2012, nr 9, s. 561-565.

[15] Zarzycki B., Piasta W.: Wplyw objętości zaczynu cementowego na konsystencję mieszanek do wysokowartościowych betonów samozagęszczalnych i masywnych. Budownictwo i Architektura 2015, nr 14(2), s. 123-130.

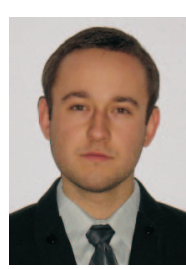

Dr inż. Marcin KREMIENIEWSKI

Adiunkt w Zakładzie Technologii Wiercenia. Instytut Nafty i Gazu - Państwowy Instytut Badawczy ul. Lubicz 25 A

31-503 Kraków

E-mail: marcin.kremieniewski@inig.pl 